\title{
Climate change and the detection of trends in annual runoff
}

\author{
Gregory J. McCabe $\mathrm{Jr}^{1, *}$, David M. Wolock ${ }^{2}$ \\ ${ }^{1}$ U.S. Geological Survey, Denver Federal Center, MS 412, Denver, Colorado 80225, USA \\ ${ }^{2}$ U.S. Geological Survey, 4821 Quail Crest Place, Lawrence, Kansas 66049, USA
}

\begin{abstract}
This study examines the statistical likelihood of detecting a trend in annual runoff given an assumed change in mean annual runoff, the underlying year-to-year variability in runoff, and serial correlation of annual runoff. Means, standard deviations, and lag-1 serial correlations of annual runoff were computed for 585 stream gages in the conterminous United States, and these statistics were used to compute the probability of detecting a prescribed trend in annual runoff. Assuming a linear $20 \%$ change in mean annual runoff over a $100 \mathrm{yr}$ period and a significance level of $95 \%$, the average probability of detecting a significant trend was $28 \%$ among the 585 stream gages. The largest probability of detecting a trend was in the northwestern U.S., the Great Lakes region, the northeastern U.S., the Appalachian Mountains, and parts of the northern Rocky Mountains. The smallest probability of trend detection was in the central and southwestern U.S., and in Florida. Low probabilities of trend detection were associated with low ratios of mean annual runoff to the standard deviation of annual runoff and with high lag-1 serial correlation in the data.
\end{abstract}

KEY WORDS: Runoff Climate change Trends - United States

\section{INTRODUCTION}

Scientists have estimated that increasing concentrations of atmospheric carbon dioxide and other radiatively active gases will cause changes in regional temperature and precipitation (Gammon et al. 1985, Bolin 1986, Lins et al. 1988, Mitchell et al. 1990). There is concern that changes in climate may affect hydrologic processes, such as snowpack accumulation and melt, evapotranspiration, streamflow, and recharge to subsurface storage (Gleick 1987, 1989, Rango \& van Katwijk 1990, Kuhn \& Parker 1992).

Over the past 10 to 15 yr there have been numerous studies of the hydrologic effects of climate change (Nemec \& Schaake 1982, Idso \& Brazel 1984, Wigley \& Jones 1985, Mather \& Feddema 1986, Gleick 1987, 1989, Karl \& Riebsame 1989, McCabe \& Ayers 1989, Lettenmaier \& Gan 1990, Schaake 1990, McCabe \& Wolock 1991, Nash \& Gleick 1991, Wolock \& Hornberger 1991, Ayers et al. 1994, McCabe \& Hay 1995).

\footnotetext{
·E-mail:gmccabe@usgs.gov
}

These studies primarily have focused on the effects of changes in temperature and precipitation on mean monthly, seasonal, or annual runoff. In some instances, the simulated effects of changes in climate variables produced large percentage changes in simulated runoff (Gleick 1989, Lettenmaier \& Gan 1990, Nash \& Gleick 1991, Ayers et al. 1994, McCabe \& Hay 1995). Only a few of these studies, however, discuss whether these changes are likely to be detected in measured hydrologic time series data.

Many studies of climate trends have focused on trends in temperature and precipitation (e.g. Solow 1987, Karl \& Riebsame 1989, Karl et al. 1989, Solow \& Broadus 1989). In this study, however, trends in runoff are evaluated for 2 reasons: (1) runoff represents the integration of climatic variables over space; and (2) runoff is especially useful in the mountainous western U.S. because it includes water from high elevation locations where no precipitation measurements are made. There are numerous runoff time series available in the conterminous U.S. that are long and continuous; these time series facilitate an analysis of trends in runoff 
Some previous investigations have addressed various aspects of runoff or streamflow trends and their relations to climate. Wahl (1991) examined trends in annual runoff measured at 58 stations in the western conterminous U.S. for periods ranging from 37 to 81 yr in length and all ending in 1989. Wahl found statistically significant trends in anmual runoff at a $95 \%$ confidence level at only 5 of the 58 stations examined. Annual runoff at only 1 of 10 stations examined in California indicated significant trends in annual runoff, even though California had been experiencing a drought during the late 1980 s. Thus, even with notable changes in climatic conditions, statistically significant trends in annual runoff were difficult to detect.

Chiew \& McMahon (1993) examined trends in annual streamflow of 30 unregulated Australian rivers to identify changes in streamflow related to changes in climate. The authors did not find evidence of changes in streamflow resulting from climate change. Further, they indicated that the detection of statistically significant trends in streamflow is largely affected by interannual variability in streamflow and to a lesser degree to the length of streamflow record.

Lettenmaier et al. (1994) examined trends in annual runoff in the conterminous U.S. for the period 1948 to 1988. Two areas where they found a large number of significant trends in annual runoff are the northwestern U.S, along the Pacific coast (the Pacific Northwest) and the area just west of the Great Lakes (the Great Lakes Region). The annual runoff time series in the Pacific Northwest indicated significant decreasing trends although annual precipitation at only a few stations in the Pacific Northwest indicated significant decreasing trends. Temperature records in the Pacific Northwest, however, indicated significant increasing trends in annual mean temperature. Lettenmaier et al. found increasing trends in annual runoff and annual precipitation for many locations in the Great Lakes Region, and increasing trends in annual mean temperatures in the western Great Lakes Region. Notably, they found few significant trends in annual runoff in the central U.S. even though significant increasing trends in annual precipitation and significant decreasing or increasing trends in annual mean temperature were identified for many locations in that region. Consequently, Lettenmaier et al. indicated that trends in temperature and precipitation alone do not explain the spatial distribution of significant trends in runoff.

Because there is concern that potential climate change may affect runof, it is important to detect these changes and to understand the factors that affect the statistical detection of trends in runoff. It also is important to under- stand what magnitudes of change in runoff are needed to be detected statistically. The objective of this study is to examine the statistical likelihood of detecting an assumed trend in annual runoff in the conterminous U.S. The approach is based on statistical theory presented by Lettenmaier (1976) and is applied to annual runoff data at stream gages located throughout the conterminous U.S. In this study, a linear trend in mean annual runoff of a prescribed magnitude is assumed. and the probability of detecting this trend in measured data is evaluated using Spearman's Rho, a nonparametric trend test.

\section{TREND DETECTION}

The detection of trends in measured time series data can be posed as a hypothesis testing problem in which the null hypothesis $\left(H_{0}\right)$ is that there is no trend in the data, and the alternate hypothesis $\left(H_{1}\right)$ is that there is a trend in the data. Reality (truth) will be that either the null or the alternate hypothesis is true, and a statistical test will indicate that either the null or the aiternate hypothesis is true (Fig. 1). The power of a statistical test is the probability of accepting the alternate hypothesis when the alternate hypothesis is true The power of a statistical test for trend then would be the probability of detecting a trend when there really is a trend or, in the case of our study, when a trend is prescribed.

The power of Spearman's Rho can be approximated by a cumulative normal distribution (with an adjustment for the effective independent sample size, see Eq. 4) with the argument $P$ (Lettenmaier 1976):

$$
P=N_{T}-T_{\text {CRIT }}
$$

where $T_{\mathrm{CRIT}}$ is the critical value for a chosen significance level (e.g. 1.96 for the $95 \%$ confidence level), and $N_{T}$ is a noncentrality parameter.

Statistical test indication

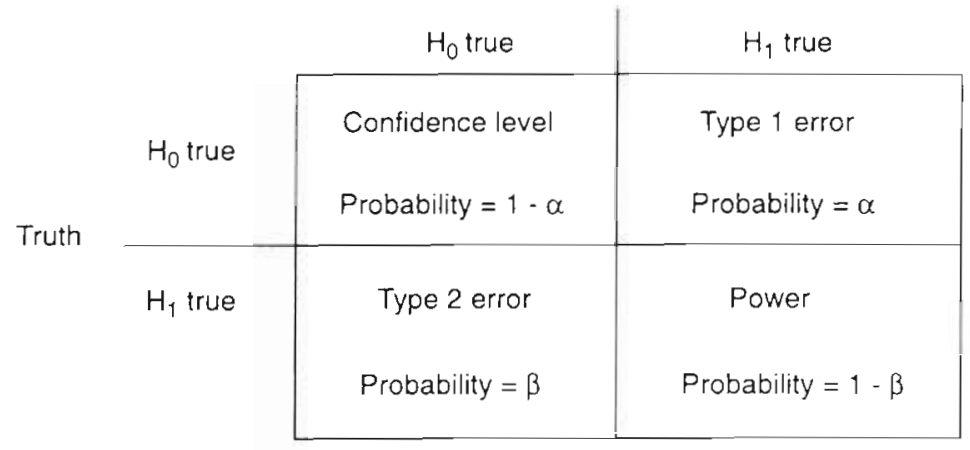

Fig. 1. Probability of possible outcomes during hypothesis testing 
The noncentrality parameter $\left(N_{T}\right)$ for Spearman's Rho to detect an assumed linear trend is given by (Lettenmaier 1976):

$$
N_{T}=\frac{T_{r} \sqrt{n_{b}}}{\sqrt{12 \sigma}}
$$

where $T_{r}$ is the magnitude of the trend, $n_{b}$ is the effective number of independent samples, and $\sigma$ is the standard deviation of annual runoff for a stream gage. In this study $T_{r}$ is assumed to be 0.2 times the mean annual runoff $(\bar{x})$ for a stream gage, so Eq. (2) becomes:

$$
N_{T}=\frac{0.2 \bar{x} \sqrt{n_{b}}}{\sqrt{12} \sigma}
$$

The effective number of independent samples $\left(n_{b}\right)$ is a function of the total number of observations and the serial correlation among the observations. The effect of serial correlation on the number of independent samples has been derived for a lag-1 correlated time series (Bayley \& Hammersley 1946, Matalas \& Langbein 1962, Lettenmaier 1976, Lettenmaier \& Burges 1978), and is given by:

$$
\frac{1}{n_{b}}=\frac{1}{n}+\frac{2}{n^{2}} \frac{\rho^{(n+1) t}-n \rho^{2 t}+(n-1) \rho^{t}}{\left(\rho^{t}-1\right)^{2}}
$$

where $n_{b}$ is the effective number of independent samples, $n$ is the original number of observations, $\rho$ is the absolute value of the lag-1 serial correlation, and $t$ is the sample interval. Fig. 2 illustrates the relation between lag-1 serial correlation values and the effective number of independent samples given a time series with 100 observations. (The lag-1 serial correlations were computed from annual runoff measured at the 585 stream gages used in this study; see below.)

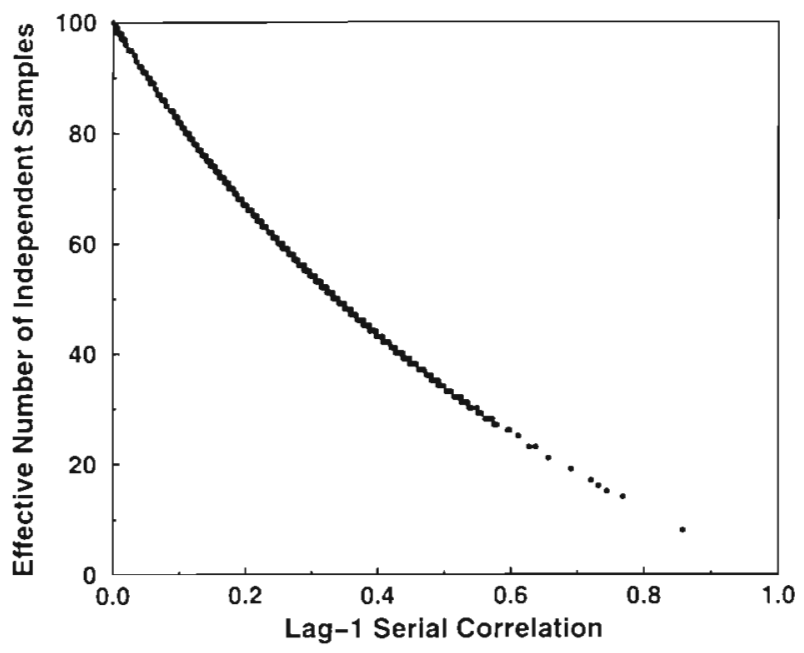

Fig. 2. Lag-1 serial correlations and the effective number of independent samples given a time series of 100 observations

\section{RUNOFF DATA}

The long-term mean, standard deviation, and lag-1 serial correlation of annual runoff data were computed for 585 stream gages in the conterminous U.S. (Fig. 3). The environmental settings of these 585 gages represent a range of climate and physiographic conditions. These stream gages were chosen based on 2 criteria: (1) the streamflow record at each gage had to include a complete record of annual runoff for the years 1951 to 1980 ( $30 \mathrm{yr}$ ), and (2) the drainage basin area had to be equal to or less than $2500 \mathrm{~km}^{2}$. Drainage basins of this size were used so that the streamflow measured at a gage would be the result of relatively homogeneous climate conditions. Data for these gages were obtained from the Hydro-Climatic Data Network (HCDN) published by the U.S. Geological Survey (Slack \& Landwehr 1992). The streamflow records included in the HCDN are from measurements made on unregulated streams that are relatively free from anthropogenic influences (Slack \& Landwehr 1992); any human effects on these streams are considered to be small and to not mask the effects of climatic variation on streamflow. There may be some errors in the data set, but for the purpose of this paper these errors are not significant. The size of drainage basins ranged from 5 to $2484 \mathrm{~km}^{2}$, with a median size of $648 \mathrm{~km}^{2}$. The annual streamflow data for each gage were converted to values of annual runoff (in $\mathrm{mm}$ ) by dividing by the respective drainage areas.

\section{RESULTS AND DISCUSSION}

The means, standard deviations, and lag-1 serial correlations computed from the $30 \mathrm{yr}$ of annual runoff data at each of the 585 stream gages were used with Eqs. (1), (3) \& (4) to determine the power of Spearman's Rho. The power of the test in this application is the probability of detecting a statistically significant linear trend in annual runoff (at a 95\% confidence level) given an assumed linear $20 \%$ change in mean annual runoff over a 100 yr period.

The power values for the 585 stream gages ranged from 5 to $94 \%$ with a mean of $28 \%$ (Fig. 4). Even for a time series $100 \mathrm{yr}$ in length and for an assumed change in mean annual runoff of $20 \%$ over $100 \mathrm{yr}$, the probability of detecting a linear trend for most locations in the conterminous U.S. is small. The spatial distribution of power values (Fig. 5) indicates that the highest probability of detecting a trend is in the northwestern U.S., the Great Lakes region, the northeastern U.S., the Appalachian Mountains, and parts of the northern Rocky Mountains. The smallest probability of trend detection is in the central and southwestern U.S., and in Florida. 


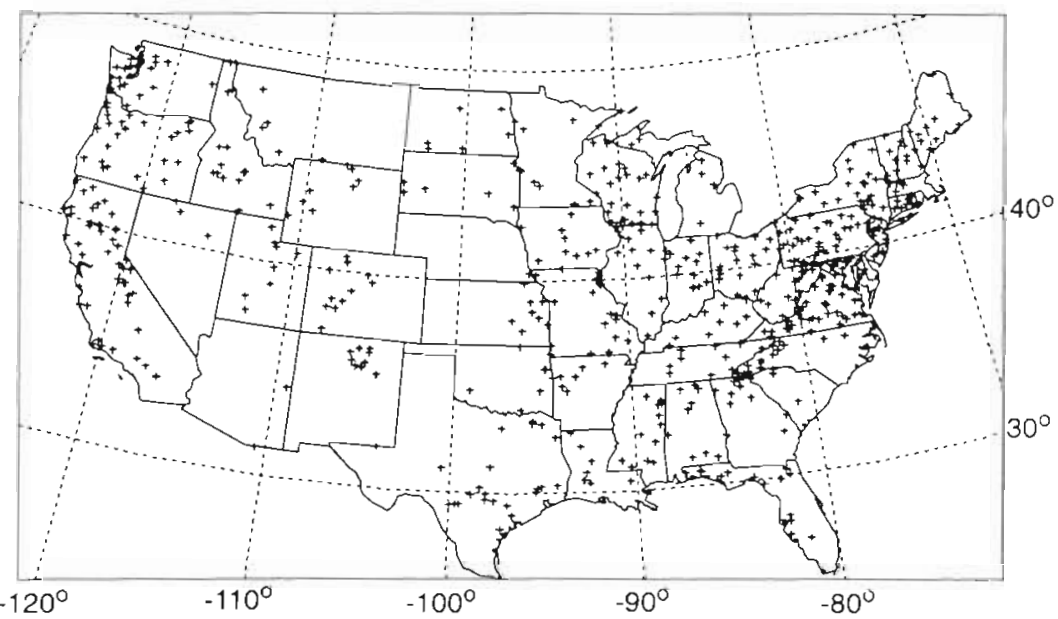

Fig. 3. Locations of stream gages in the conterminous United States (e.g. the central and southwestern U.S.) that were not accompanied by detectable trends in annual runoff. The results of this study indicate that changes in annual runoff are difficult to detect in these regions (Fig. 5). Annual runoff in these regions has a low ratio of mean to standard deviation $(\bar{X} / \sigma)$; thus statistical detection of trends is difficult.

The magnitude of the percentage change in mean annual runoff that would result in a $50 \%$ chance of detecting a trend in runoff was computed for each of the stations included in this study (Fig. 7). (Trends were detected using Spearman's Rho at a $95 \%$ confidence level for 100 yr time series.i
The factors that affect the probability of trend detection are the magnitude of the assumed trend, the yearto-year variability in the runoff data, the magnitude of the serial correlation in the runoff data, the number of observations in the data record, and the statistical significance level of the trend test (see Eqs. 1 to 4). The length of the data record was assumed constant for all stream gages, the magnitude of the trend was assumed to be $20 \%$ of the mean annual runoff value at all gages, and the $95 \%$ confidence level was used for all tests. Therefore, differences in the probability of trend detection among the gages can be related entirely to differences in the ratio of the mean annual runoff to the standard deviation $(\vec{x} / \sigma)$ and lag- 1 serial correlation $(p)$ of annual runoff at the gages. The effects of the ratio of mean annual runoff to the standard deviation and lag-1 serial correlation on trend detection are illustrated in Fig. 6, which shows contour lines of power values from the 585 stream gages. A high ratio of mean annual runoff to standard deviation increases the value of the noncentrality parameter $\left(N_{T}\right)$ and thereby also the power value. A high magnitude value (positive or negative) for the lag-1 serial correlation decreases the number of effective independent samples $\left(n_{b}\right)$ and decreases the power of the trend test. The effects of lag-1 serial correlation on trend detection are highest for high ratios of mean annual runoff to the standard deviation.

Wahl (1991) and Lettenmaier et al. (1994) indicated significant changes in. temperature and precipitation for various parts of the conterminous U.S.

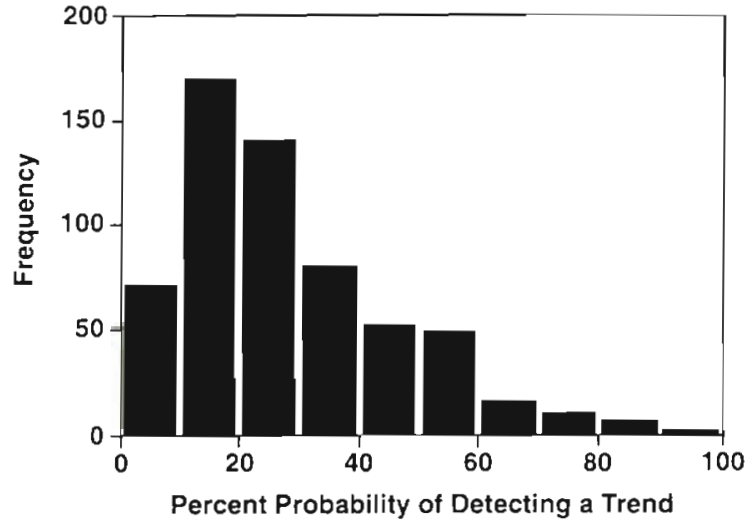

Fig. 4. Probability of detecting a trend in annual runoff (at a $95 \%$ confidence level) given a linear $20 \%$ change in mean annual runoff over a 100 yr period

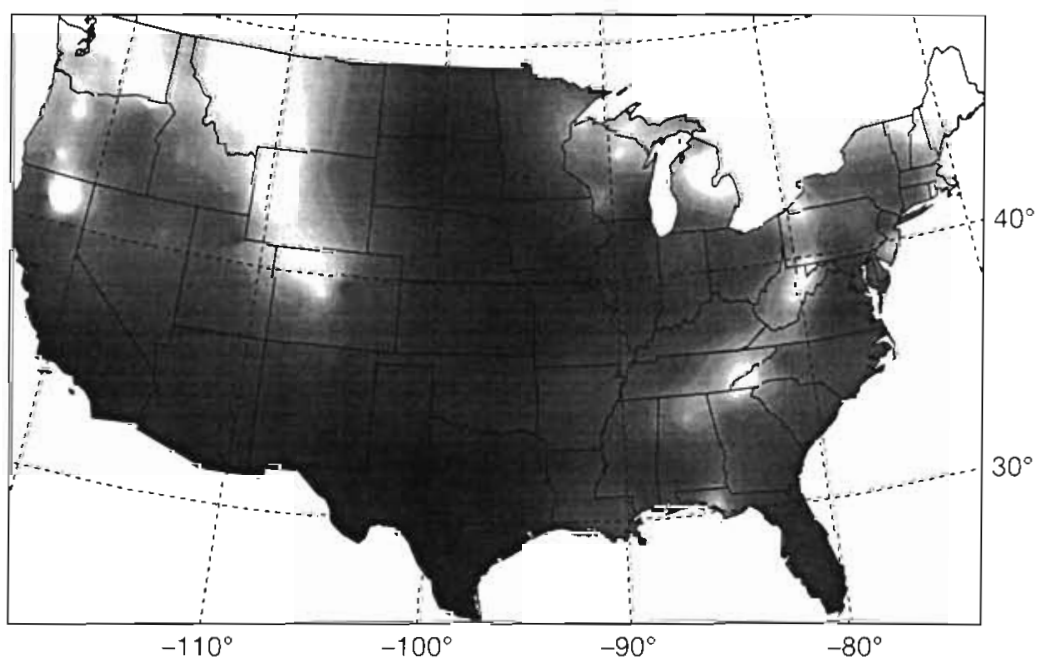

Fig. 5. Spatial distribution of the probability of detecting a trend in annual runoff (at a $95 \%$ confidence level) given a linear $20 \%$ change in mean annual runoff over a 100 yr period. Dark shading indicates low probabilities and light shadıng indicates high probabilities 


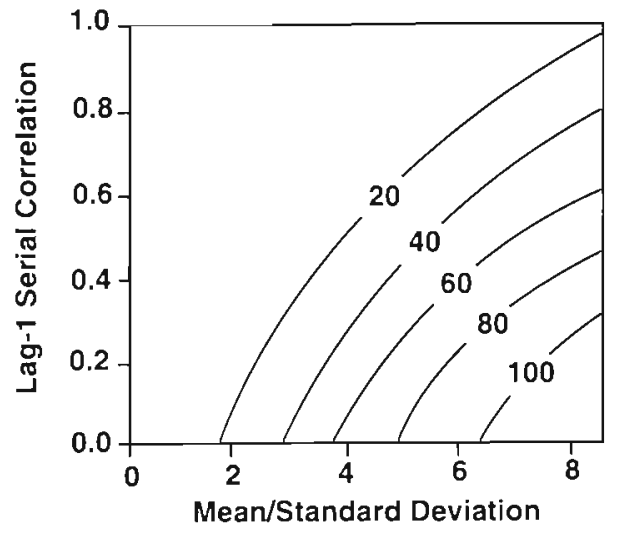

Fig. 6. Effects of the ratio of mean annual runoff to standard deviation and lag-1 serial correlation on the probability (in percent) of detecting a trend in annual runoff given a linear $20 \%$ change in mean annual runoff over a 100 yr period

Results indicate that, on average, a $37 \%$ change in mean annual runoff over a $100 \mathrm{yr}$ period is necessary. The required percentage change in mean annual runoff ranges from 12 to $124 \%$ among the 585 stream gages, and the first and third quartile values are 25 and $44 \%$, respectively.

Very simple hypothetical effects of climate change were used in this study: (1) a uniform $20 \%$ change in mean annual runoff was assumed for all locations in the conterminous U.S.; and (2) variability and serial correlation in annual runoff were assumed to remain constant at 1951-1980 levels. Almost certainly, the hydrologic effects of climate change will not be a uniform percentage change across the conterminous U.S., and variability in climate and hydrologic variables will not stay at current levels. Climate models project increases in precipitation to be greatest at high latitudes during winter, and decreases in soil-moisture are projected to be greatest for some mid-latitude continental regions during summer (Mitchell et al. 1990).

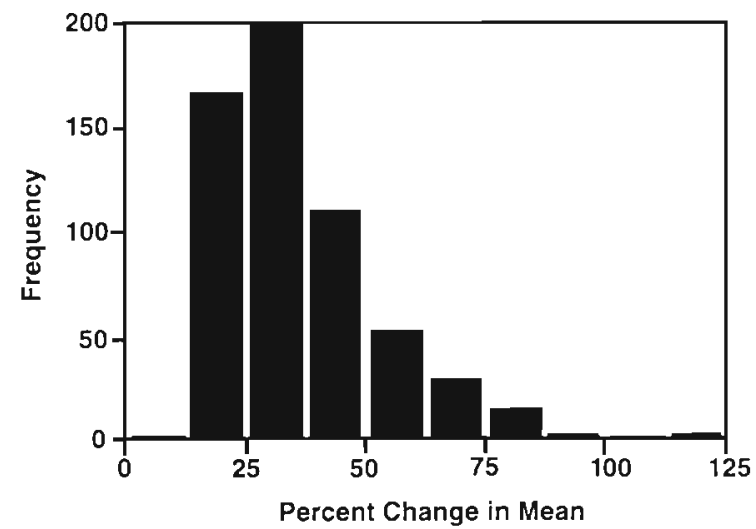

Fig. 7. Percent change in mean annual runoff over a $100 \mathrm{yr}$ period needed to detect a trend in annual runoff (at a 95\% confidence level) with a probability of $50 \%$
Spatial differences in climate change will affect the spatial patterns of detectability, such as the one illustrated by Fig. 5. Also, there are factors other than climate change that cause trends in runoff, such as land-use change and changes in water-management practices. The spatial patterns of detectability of trends in runoff will be affected by these factors as well.

This study suggests that the probability of detecting trends in measured annual runoff may be very low, even if there are real underlying trends in the data such as trends caused by climate change. Unless changes in runoff are large, long time series of runoff observations will be needed to detect statistically any trends. Caution must be taken, however, when interpreting the physical importance (or lack thereof) of non-statistically significant trends in annual runoff. A trend in runoff may not be statistically significant, but could have important effects on water resources.

\section{LITERATURE CITED}

Ayers MA, Wolock DM, McCabe GJ, Hay LE, Tasker GD (1994) Sensitivity of water resources in the Delaware River basin. US Geological Survey Water-Supply Paper 2422. US Geological Survey, Reston, VA

Bayley GV, Hammersley JM (1946) The effective number of independent observations in an autocorrelated time series. J R Statist Soc 8:184-197

Bolin $\mathrm{B}$ (1986) How much $\mathrm{CO}_{2}$ will remain in the atmosphere? In: Boilin B, Doos DR, Jager J, Warrick R (eds) The greenhouse effect, climate change, and the ecosystem. John Wiley, New York, p 93-155

Chiew FHS, McMahon TA (1993) Detection of trend or change in annual flow of Australian rivers. Int J Climatol 13:643-653

Gammon RH, Sundquist ET, Fraser OJ (1985) History of carbon dioxide in the atmosphere. In: Trabalka JR (ed) Atmospheric carbon dioxide and the global carbon cycle. US Department of Energy, Washington, DC, p 25-62

Gleick PH (1987) Regional hydrologic consequences of increases in atmospheric $\mathrm{CO}_{2}$ and other trace gases. Clim Change 10:137-161

Gleick PH (1989) Climate change, hydrology, and water resources. Rev Geophys 27:329-344

Idso SB, Brazel AJ (1984) Rising atmospheric carbon dioxide concentrations may increase streamflow. Nature 312:51-53

Karl TR, Riebsame WE (1989) The impact of decadal fluctuations in mean precipitation and temperature on runoff: a sensitivity study over the United States. Clim Change 15: $423-447$

Karl TR, Tarpley JD, Quayle RG, Diaz HF, Robinson DA, Bradley RS (1989) The recent climate record: what it can and cannot tell us. Rev Geophys 27:405-430

Kuhn G, Parker RS (1992) Transfer of watershed-modelparameter values to noncalibrated basins in the Gunnison River Basin, Colorado. In: Herrmann R (ed) Proceedings, managing water resources during global change. American Water Resources Association, Bethesda, MD, p $741-751$

Lettenmaier DP (1976) Detection of trends in water quality data from records with dependent observations. Water Resour Res 12:1037-1046 
Lettenmaier DP, Burges SJ (1978) Climate change: detection and its impact on hydrologic design. Water Resour Res $14: 679-687$

Lettenmaier DP, Gan TY (1990) Hydrologic sensitivities of the Sacramento-San Joaquin River basin, California, to global warming. Water Resour Res 26:69-86

Lettenmaier DP, Wood EF, Wallis JR (1994) Hydroclimatological trends in the continental United States, 1948-1988. J Clim 7:586-607

Lins HF, Sundquist ET, Ager TA (1988) Information on selected climate and climate-change issues. US Geological Survey Open-File Report 88-718. US Geological Survey, Reston, VA

Matalas NC, Langbein WB (1962) Information content of the mean. J Geophys Res 67:3441-3448

Mather JR, Feddema J (1986) Hydrologic consequences of increases in trace gases and $\mathrm{CO}_{2}$ in the atmosphere. In: Effects of changes in stratospheric ozone and global climate, Vol 3. Climate change. US Environmental Protection Agency, Washington, DC, p 251-271

McCabe GJ, Ayers MA (1989) Hydrologic effects of climate change in the Delaware River basin. Water Resour Bull $25: 1231-1242$

McCabe GJ, Hay LE (1995) Hydrological effects of hypothetical climate change in the East River basin, Colorado. J Hydrol Sci 40:303-318

McCabe GJ, Wolock DM (1991) Detectability of the effects of a hypothetical temperature increase on the Thornthwaite moisture index. J Hydrol 125:25-35

Mitchell JFB, Manabe S, Meleshko V, Tokioka T (1990) Equilibrium climate change-and its implications for the future. In: Houghton JT, Jenkins GJ, Ephraums JJ (eds) Climate change: the IPCC scientific assessment. Cam-

Editor: B. Yarnal, University Park, Pennsylvania, USA bridge University Press, New York, p 131-172

Nash LL, Gleick PH (1991) Sensitivity of streamflow in the Colorado Basin to climatic changes. J Hydrol 125:21-241

Nemec J, Schaake JS (1982) Sensitivity of water resources systems to climate variation. J Hydrol Sci 27:327-343

Rango A, van Katwijk V (1990) Water supply implications of climate change in western North American basins. In: Froceedings, international and transboundary water resources issues. American Water Resources Association, Bethesda, MD, p 577-586

Schaake JS (1990) From climate to flow. In: Waggoner PE (ed) Climate change and US water resources. John Wiley, New York, p 177-206

Slack JR, Landwehr JM (1992) Hydro-climatic data network (HCDN): a US Geological Survey streamflow data set for the United States for the study of climate variations, 1874-1988. US Geological Survey Open-File Report 92129, Reston, VA

Solow AR (1987) Testing for climate change: an application of the two-phase regression model. J Clim Appl Meteorol 26:1401-1405

Solow AR, Broadus JM (1989) On the detection of greenhouse warming. Clim Change 15:449-453

Wahl KH (1991) Is April to July runoff really decreasing in the western United States? In: Shafen B (ed) Proceedings, western snow conference, Juneau, AK. Colorado State University Press, Fort Collins, CO, p 67-78

Wigley TML, Jones PD (1985) Influences of precipitation changes and direct $\mathrm{CO}_{2}$ effects on streamflow. Nature 314 : $149-152$

Wolock DM, Hornberger GM (1991) Hydrological effects of changes in levels of atmospheric carbon dioxide. J Forecast 10:105-116

Manuscript first received: November 5, 1996

Revised version accepted: March 12, 1997 